\title{
Pengaruh Epoxy Terhadap Sifat Mekanik Beton Dengan Bahan Tambah Kaca Sebagai Substitusi Agregat Halus
}

\author{
Ade LISANTONO $^{1 *} \cdot$ Evander TANDEAN $^{2}$ \\ ${ }^{1}$ Program Studi Teknik Sipil, Universitas Atma Jaya Yogyakarta, email: adelisantono@mail.uajy.ac.id \\ ${ }^{2}$ Program Studi Teknik Sipil, Universitas Atma Jaya Yogyakarta, email: evtandean@gmail.com
}

\begin{abstract}
Generally concrete consists of cement, water, sand and gravel. To increase the adhesion of concrete materials is adding epoxy to the concrete. While, to make the concrete has a good in water-resistant is adding glass powder which is expected to fill the air cavity in the concrete. This study aims to determine the adhesion of epoxy to glass with aggregates in a concrete mixture. Substitution of fine aggregate with glass powder is $50 \%$ by weight of fine aggregate and the use of epoxy is $10 \%$ by weight of cement. Test specimens were cylindrical with the size of $(150 \times 300) \mathrm{mm}$. Specimens with the size of $(500 \times 100 \times 100) \mathrm{mm}$ were also made. The Tests were carried out at the age of 14 and 28 days of concrete. Three variations were made, namely normal concrete, concrete with glass powder, and concrete with glass powder plus epoxy. The test results show that the substitution of glass powder can improve the mechanical properties of concrete, while the addition of epoxy does not significantly influence the mechanical properties of concrete with glass powder.
\end{abstract}

Keywords: concrete, epoxy, glass powder, sand substitution, mechanics properties

\section{Pendahuluan}

Kebutuhan bahan bangunan untuk pekerjaan konstruksi terus meningkat seiring dengan berkembangnya zaman. Dunia teknologi bahan konstruksi mengalami kemajuan yang pesat dari tahun ke tahun. Salah satu contoh yaitu perkembangan teknologi beton. Hal ini dikarenakan beton merupakan salah satu bahan konstruksi yang paling banyak digunakan dalam proyek konstruksi. Beton merupakan campuran dari semen, kerikil, pasir, dan air. Beton memiliki beberapa kelebihan yaitu memiliki kuat tekan yang tinggi, proses pembuatannya mudah sekaligus dimensinya dapat disesuaikan dengan bentuk yang diinginkan, serta dengan harga yang relatif terjangkau. Pada kondisi tertentu, beton dapat diberikan bahan tambah dalam kadar tertentu dengan tujuan untuk meningkatkan kekuatan dari beton tersebut khususnya dalam hal kuat tekan dan daktilitas.

Berbagai penelitian yang telah dilakukan (Nugrahani, 2014 dan Yulius, 2015) menunjukkan bahwa penambahan zat epoxy pada beton dapat meningkatkan kualitas serta menutupi kelemahan dari beton itu sendiri. Epoxy yang dipakai pada campuran beton umumnya adalah epoxy resin. Selain menambahkan epoxy, beton tersebut juga akan ditambahkan kaca guna untuk mengurangi limbah kaca dari suatu industri yang sudah tidak memiliki nilai jual lagi. Nugrahani (2014) dalam penelitiannya menyimpulkan bahwa penambahan epoxy pada beton dengan umur 28 hari dapat meningkatkan kuat tekan beton dibandingkan dengan beton normal tanpa penambahan epoxy. Sedangkan Yulius (2015) dalam penelitiannya menyimpulkan bahwa epoxy memiliki karakteristik yang baik dan cocok untuk digunakan dalam campuran beton, sehingga dapat bereaksi dengan baik.

*penulis korespondensi 
Penelitian yang telah dilakukan oleh (Fanisa, 2013 dan Ayu, 2014) menunjukkan bahwa penambahan kaca sebagai substitusi agregat halus dapat membuat beton menjadi kedap air karena partikel-partikel kaca yang kecil dapat mengisi rongga-rongga dalam beton sehingga membuat beton menjadi kedap air. Selain kedap air, beton dengan tambahan kaca dapat meningkatkan kuat tekannya. Beton dengan tambahan kaca merupakan beton yang ramah lingkungan karena memanfaatkan limbah kaca sebagai campuran dalam beton. Fanisa (2013) dalam penelitiannya menyimpulkan bahwa kuat tekan beton terus mengalami kenaikan seiring bertambahnya persentase bubuk kaca pada beton. Sedangkan Ayu (2014) dalam penelitiannya menyimpulkan bahwa semakin besar penambahan tumbukan kaca sebagai substitusi agregat halus maka semakin besar nilai kuat lentur beton.

Melihat latar belakang yang telah disampaikan di atas, maka masih diperlukan penelitian mengenai pengaruh penggunaan zat epoxy terhadap beton normal dengan tambahan kaca terhadap sifat mekanik beton, yaitu kuat tekan, kuat lentur dan modulus elestisitas.

\section{Tinjauan Pustaka}

Resin epoxy atau secara umum di pasaran dikenal dengan bahan epoxy adalah salah satu dari jenis polimer yang berasal dari kelompok thermoset. Resin thermoset adalah polimer cair yang diubah menjadi bahan padat secara polimerisasi jaringan silang dan juga secara kimia, membentuk formasi rantai polimer tiga dimensi. Resin epoxy banyak digunakan untuk bahan struktural, sehingga pada beton penggunaan resin epoxy dapat mempercepat proses pengeringan, karena epoxy menimbulkan panas dan dapat membantu percepatan pengerasan (Gemert, 2004).

Kaca adalah material padat yang bening dan transparan (tembus pandang), biasanya rapuh. Jenis yang paling banyak digunakan selama berabad-abad adalah jendela dan gelas minum. Kaca dibuat dari $75 \%$ silikon dioksida ( $\mathrm{SiO} 2$ ), plus $\mathrm{Na} 2 \mathrm{O}, \mathrm{CaO}$ dan beberapa zat tambahan (Hendra, 2014). Limbah kaca merupakan limbah yang banyak dihasilkan dari kehidupan masyarakat terutama di kota besar dan kota lainnya, limbah kaca setiap hari semakin meningkat volumenya karena banyak kegiatan manusia yang menghasilkan kaca, sebagian besar limbah kaca langsung dibuang ke lahan terbuka, hal ini tentu saja akan mencemari lingkungan mengingat kaca merupakan material yang tidak dapat didaur ulang secara alami oleh alam (Ayu, 2014).

Joksan (2015) melakukan penelitian pada beton normal yang ditambahkan resin epoxy dengan proporsi penambahan sebesar 20\%, 25\%,30\%,35\%, 40\% (dengan persentase berat dari total agregat). Hasil penelitiannya menunjukkan bahwa kondisi optimum diperoleh pada perbandingan 65:35\% didapatkan kuat tekan 6,80 MPa, dan kuat tarik belah sebesar 1,75 $\mathrm{MPa}$. Percobaan dilakukan dengan menggunakan beton berumur 24 jam atau 1 hari.

Sedangkan Yulius (2015) juga melakukan penelitian pada beton normal yang ditambahkan resin epoxy dan abu vulkanik Gunung Sinabung, dimana resin epoxy sebagai material polimer. Benda uji dibuat sebanyak 5 sampel untuk beton polimer dan untuk beton normal 5 sampel dengan variasi: (5\% abu $+5 \%$ epoxy), $(12 \%$ abu $+7 \%$ epoxy $),(25 \%$ abu $+10 \%$ epoxy) dengan mutu beton normal rencana sebesar 17,50 MPa. Hasil penelitian memperlihatkan bahwa besarnya kuat tekan yang dihasilkan untuk masing-masing variasi di atas secara berurutan adalah: $14,83 \mathrm{MPa}, 22,53 \mathrm{MPa}, 25,36 \mathrm{MPa}$, sedangkan beton normal memiliki kuat tekan sebesar 18,74 MPa. Hal ini membuktikan bahwa peningkatan kuat tekan beton dapat dicapai dengan menggunakan epoxy lebih dari $5 \%$. 
Penelitian yang dilakukan oleh Nugrahani (2014) pada beton polimer epoxy dengan memanfaatkan limbah yang telah banyak dikembangkan, salah satunya dengan limbah cangkang kerang dan lumpur Sidoarjo. Cangkang kerang dan lumpur Sidoarjo dipakai sebagai nanokalsit dan nanosilika yang dipakai sebagai filler pada beton polimer. Hasil pengujiannya diperoleh bahwa beton polimer dengan komposisi $10 \%$ kalsit $+10 \%$ silika mendapatkan kuat tekan yang paling besar yaitu 218,39 MPa, kuat tarik 3,32 MPa, kuat patah $8,04 \mathrm{MPa}$.

Fanisa (2013) melakukan penelitian beton dengan jumlah persentase kaca yang besar lebih dari berat pasir, membuat kuat tekan beton terus meningkat dengan berat yang semakin ringan. Namun penambahan kaca tersebut membuat workabilitas beton semakin menurun.

Sedangkan penelitian yang dilakukan oleh Ayu (2014) menyatakan bahwa penambahan tumbukan botol kaca sebesar 2,5\% ini dapat menambah kuat tekan beton sebesar 7,57 \% dari kuat tekan beton normal. Namun, penambahan tumbukan botol kaca sebesar 5\% akan mengurangi mutu beton sebesar 3,23 \%, penambahan tumbukan botol kaca sebesar 7,5\% akan mengurangi mutu beton sebesar $11,10 \%$ dan penambahan tumbukan botol kaca sebesar $10 \%$ akan mengurangi mutu beton sebesar $20,02 \%$ dari kuat tekan beton optimum.

\section{Program Eksprimental}

\section{Material}

Material yang digunakan dalam penelitian ini adalah sebagai berikut:

1. Agregat kasar dari Clereng dengan diameter maksimal $20 \mathrm{~mm}$,

2. Agregat halus (pasir) dari Sungai Progo dengan diameter antara 0,125-0,5 mm,

3. Semen yang digunakan adalah Semen PPC (Pozollan Portland Cement),

4. Air yang digunakan berasal dari Laboratorium Struktur dan Bahan Bangunan, Program Studi Teknik Sipil, Fakultas Teknik, Universitas Atma Jaya Yogyakarta,

5. Zat epoxy yang digunakan adalah epoxy resin adhesive sebesar $10 \%$ terhadap berat semen

6. Kaca yang digunakan adalah kaca yang diperoleh dengan memanfaatkan limbah dengan penambahan persentase serbuk kaca yang digunakan sebagai substitusi pasir sebesar $50 \%$ terhadap berat pasir.

\section{Benda Uji}

Benda uji berupa silinder berukuran $(150 \times 300) \mathrm{mm}$ untuk pengujian kuat tekan dan modulus elastisitas Sedangkan untuk pengujian modulus rupture buat benda uji berukuran $(500 \times 100 \times 100) \mathrm{mm}$. Pengujian kuat tekan dan modulus elastisitas diuji pada umur beton 14 dan 28 hari. Sedangkan untuk modulus rupture diuji pada umur beton 28 hari. Jumlah benda uji yang dibuat dapat dilihat pada Tabel 1 . 
Tabel 1. Variasi Benda Uji

\begin{tabular}{|c|c|c|c|}
\hline \multirow{2}{*}{ Jenis Pengujian } & \multicolumn{2}{|c|}{ Jumlah Benda Uji } \\
\cline { 2 - 4 } & \multicolumn{2}{|c|}{$\begin{array}{c}\text { Silinder } 150 \mathrm{~mm} \times \\
300 \mathrm{~mm}\end{array}$} & $\begin{array}{c}\text { Balok 500 mm x } \\
100 \mathrm{~mm} \times 100 \mathrm{~mm}\end{array}$ \\
\cline { 2 - 4 } & $\begin{array}{c}\text { Kuat Tekan dan } \\
\text { Modulus Elastisitas }\end{array}$ & Modulus Ruptures \\
\hline Umur Beton & 14 hari & 28 hari & 28 hari \\
\hline Beton Normal (BN) & 4 & 4 & 3 \\
\hline Beton Kaca (BK dengan substitusi kaca 50\%) & 4 & 4 & 3 \\
\hline $\begin{array}{c}\text { Beton Kaca dan Epoksi (BKE dengan substitusi } \\
\text { kaca 50\% dan epoksi dengan kadar 10\%) }\end{array}$ & 4 & 4 & 3 \\
\hline Jumlah Total Benda Uji & 12 & 12 & 9 \\
\hline
\end{tabular}

\section{Pengujian}

Ada empat pengujian yang dilakukan dalam penelitian ini, yakni:

1. Pengujian kuat tekan beton berdasarkan SNI 03-1974-1990

2. Pengujian modulus elastisitas berdasarkan SNI 2847-2013

3. Pengujian kuat lentur berdasarkan ASTM C-293

4. Pengujian setting time berdasarkan ASTM C-191 dan SNI 03-6827-2002

\section{Hasil dan Pembahasan}

\section{Kuat Tekan}

Pengujian kuat tekan dilaksanakan di Laboratorium Struktur dan Bahan Bangunan Universitas Atma Jaya Yogyakarta. Pegujian kuat tekan dilakukan dengan menggunakan mesin CTM merek ELE (Lihat Gambar 1). Jumlah sampel yang diuji sebanyak 4 benda uji setiap variasi dengan total 24 benda uji untuk 3 variasi selama 14 hari dan 28 hari. Benda uji yang digunakan untuk pengujian kuat tekan adalah silinder dengan diameter $150 \mathrm{~mm}$ dan tinggi $300 \mathrm{~mm}$.

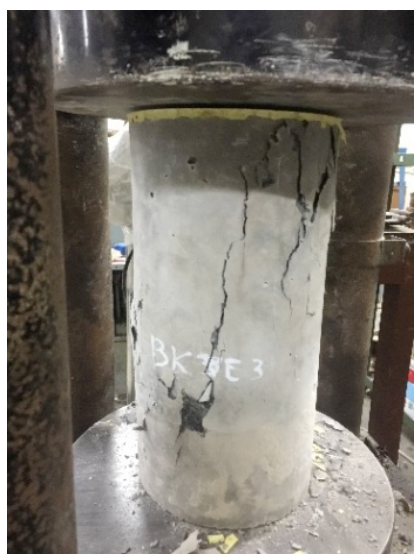

Gambar 1. Pengujian Kuat Tekan Beton 


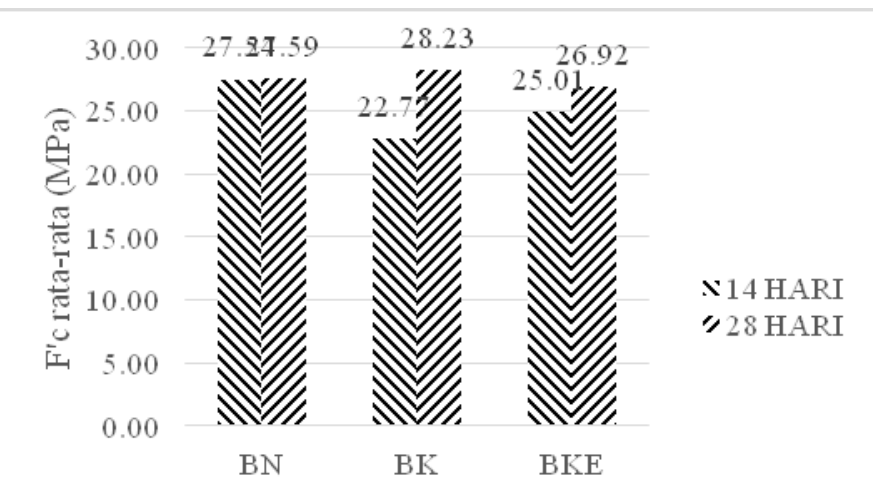

Gambar 2. Grafik Kuat Tekan Beton Normal dengan Penambahan Kaca dan Epoxy

Pada Gambar 2. menunjukkan penurunan kuat tekan beton kaca dibanding dengan beton normal dengan rasio 0,81 pada umur beton 14 hari , sedangkan pada beton kaca 28 hari terjadi peningkatan dengan rasio sebesar 1,03 dan penurunan pada beton kaca epoxy dibanding beton normal dengan rasio 0,89 pada umur beton 14 hari dan penurunan pada umur beton 28 hari dengan rasio 0,98 . Hal ini dapat disebabkan karena kaca yang digunakan dalam bentuk butiran kristalis yang ketika tersebar dalam adukan beton dapat menyebabkan kerekatan antar agregat beton sedikit berkurang dan kuat tekan beton yang dihasilkan cenderung menurun, tetapi dengan penambahan epoxy sebesar $10 \%$ kerekatan kaca dengan campuran dalam beton sedikit meningkat sehingga kuat tekan beton yang menggunakan kaca dan epoxy tidak menurun banyak.

\section{Modulus Elastisitas}

Pengujian modulus elastisitas dilaksanakan di Laboratorium Struktur dan Bahan Bangunan Universitas Atma Jaya Yogyakarta. Pengujian modulus elastisitas dilakukan dengan menggunakan mesin UTM merek Shimadzu (Lihat Gambar 3). Jumlah sampel yang diuji sebanyak 8 benda uji setiap variasi dengan total 24 benda uji untuk tiga variasi. Pengujian modulus elastisitas pada penelitian ini dimulai pada beton pertama beton normal yang berumur 14 hari hingga 28 hari. Benda uji yang digunakan untuk pengujian modulus elastisitas adalah silinder dengan diameter $150 \mathrm{~mm}$ dan tinggi $300 \mathrm{~mm}$.

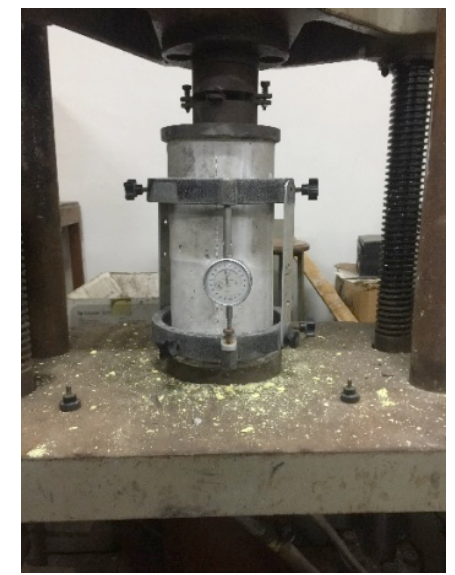

Gambar 3. Pengujian Modulus Elastisitas Beton 


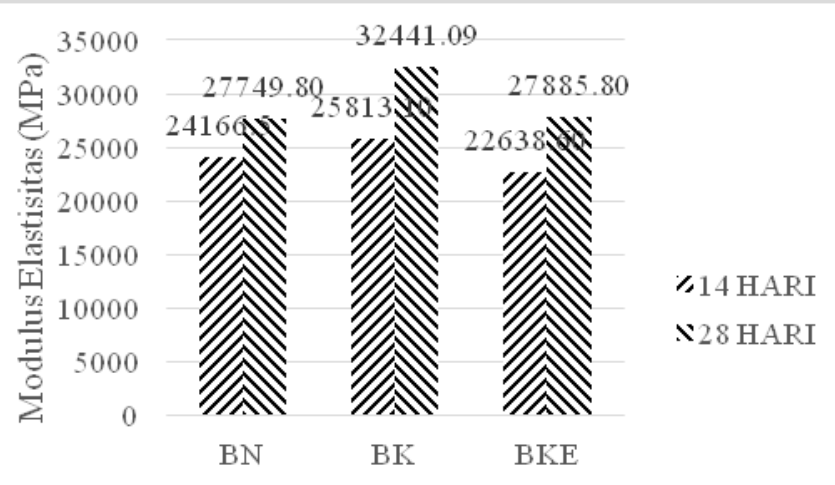

Gambar 4. Modulus Elastisitas Beton Normal, Beton Kaca dan Beton Kaca Epoxy

Hasil pengujian diperoleh modulus elastisitas rata-rata dari beton BN, BK dan BKE berturutturut adalah 25615,39 $\mathrm{MPa}, 25813,05 \mathrm{MPa}$, dan 22790,99 MPa untuk pengujian modulus 14 hari, sedangkan pengujian modulus elastisitas 28 hari berturut-turut adalah $27749,76 \mathrm{MPa}$, 32441,09 MPa, 27885,85 MPa. Terlihat peningkatan nilai modulus elastisitas pada beton normal dan beton yang ditambahkan kaca dan epoxy. Hasil tersebut didapatkan bahwa nilai modulus elastisitas paling tinggi adalah spesimen BK. Hasil pengujian modulus elastisitas dan perbandingannya dapat dilihat pada Gambar 4.

\section{Kuat Lentur (Modulus of Rupture)}

Pengujian ini dilakukan di Laboratorium Struktur dan Bahan Bangunan (LSBB), Fakultas Teknik, Program Studi Teknik Sipil, Universitas Atma Jaya Yogyakarta. Pengujian kuat lentur dilakukan dengan menggunakan mesin UTM (Universal Testing Machine) merek Shimadzu (Lihat Gambar 5). Jumlah benda uji untuk masing-masing variasi ada 3 benda uji, jadi total benda uji untuk pengujian ini berjumlah 9. Benda uji untuk pengujian kuat lentur ini berbentuk balok dengan dimensi penampang $100 \times 100 \mathrm{~mm}$ dan dengan panjang $500 \mathrm{~mm}$.

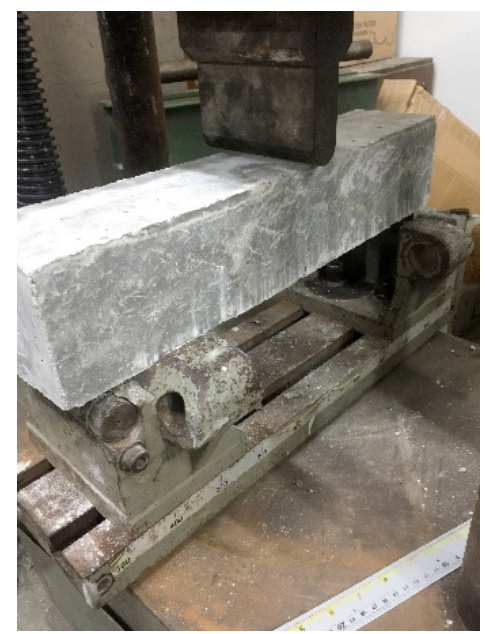

Gambar 5. Pengujian Kuat Lentur Beton 


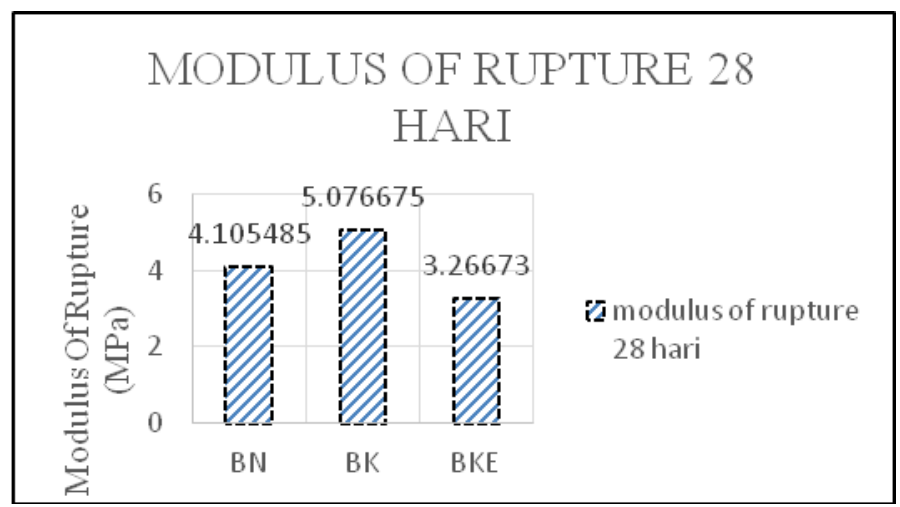

Gambar 6. Grafik Hasil Kuat Lentur Beton

Gambar 6 menunjukkan bahwa untuk beton kaca memiliki kuat lentur yang lebih besar yaitu sebesar 5,076675 MPa, sedangkan untuk beton normal dan beton kaca epoxy memiliki kuat lentur yang lebih kecil sebesar 4,105485 MPa dan 3,26673 MPa.

\section{Setting Time}

Pengujian waktu ikat awal dilakukan dengan alat jarum vicat (Lihat Gambar 7). Jumlah benda sample yang diuji sebanyak 1 benda uji dengan satu variasi. Pengujian waktu ikat awal ini dimulai dengan membuat pasta semen dari campuran semen, pasir, kaca, epoxy dan air. Pengujian ini dilakukan guna untuk mengetahui waktu ikat epoxy dengan campuran pasta tersebut dengan kadar epoxy $10 \%$ dari berat semen. Benda uji yang digunakan untuk pengujian waktu ikat awal adalah kerucut terpacung dengan diameter bawah $70 \mathrm{~mm}$, diameter atas $60 \mathrm{~mm}$, dan tinggi $40 \mathrm{~mm}$.

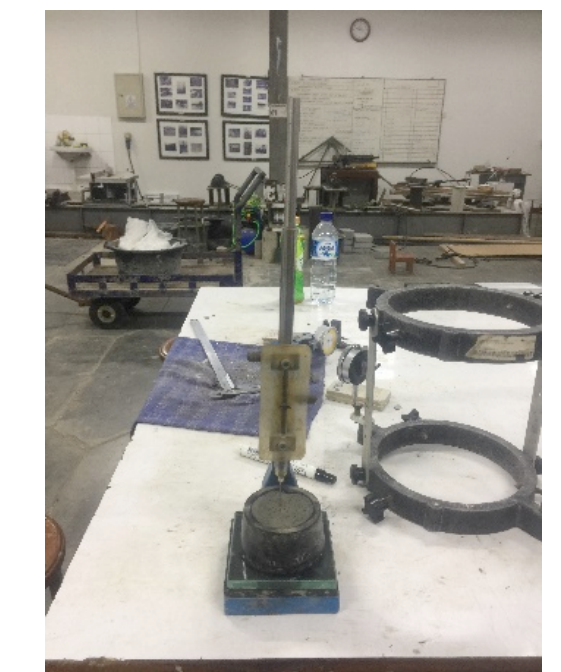

Gambar 7. Pengujian Setting Time Beton 


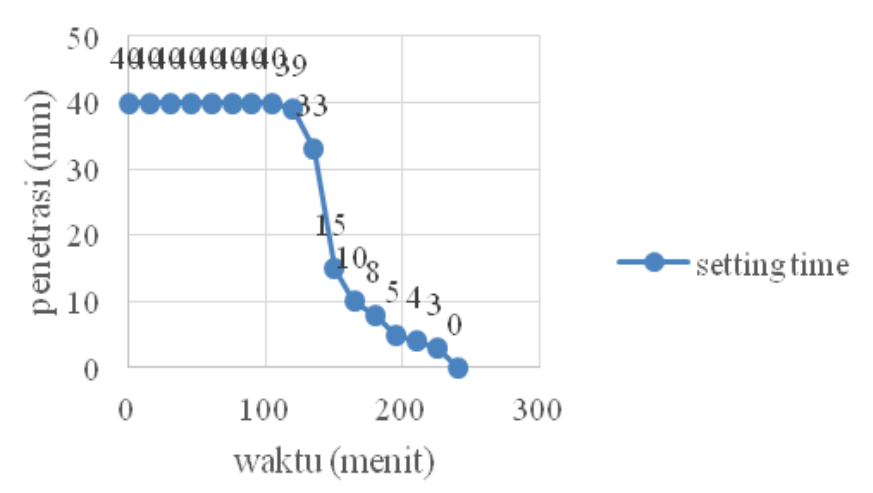

Gambar 8. Grafik Waktu Ikat Awal Campuran Semen dengan Kaca dan Epoxy

Hasil pengujian diperoleh total waktu yang diperlukan pasta untuk mengeras adalah 240 menit. Pada Tabel 2 terlihat bahwa penetrasi pasta semakin pendek ketika mencapai waktu 150 menit, waktu yang diperlukan beton normal untuk mengeras adalah berkisar selama 2 jam. Hasil waktu ikat awal dapat dilihat pada Gambar 8.

Tabel 2 Hasil Pengujian Waktu Ikat Awal Pasta Semen dengan Penambahan Kaca dan Epoksi

\begin{tabular}{|c|c|c|}
\hline Pukul & Interval Waktu (menit) & Penetrasi (mm) \\
\hline \multirow{3}{*}{11.45} & 0 & 40 \\
\cline { 2 - 3 } & 15 & 40 \\
\cline { 2 - 3 } & 30 & 40 \\
\hline \multirow{5}{*}{12.45} & 45 & 40 \\
\cline { 2 - 3 } & 60 & 40 \\
\cline { 2 - 3 } & 75 & 40 \\
\cline { 2 - 3 } & 90 & 40 \\
\hline \multirow{5}{*}{13.45} & 105 & 40 \\
\cline { 2 - 3 } & 120 & 39 \\
\cline { 2 - 3 } & 135 & 33 \\
\cline { 2 - 3 } & 150 & 15 \\
\hline \multirow{5}{*}{14.45} & 165 & 10 \\
\cline { 2 - 3 } & 180 & 8 \\
\cline { 2 - 3 } & 195 & 5 \\
\hline \multirow{4}{*}{15.45} & 210 & 3 \\
\hline
\end{tabular}

\section{Kesimpulan}

Berdasarkan hasil penelitian yang telah dilakukan, dapat ditarik beberapa kesimpulan sebagai berikut :

1. Nilai kuat tekan beton normal tanpa serbuk kaca lebih tinggi dibandingkan beton normal dengan substitusi serbuk kaca 50\% dengan rasio penurunan sebesar 0,81 pada umur 14 hari dan rasio peningkatan sebesar 1,03 pada umur 28 hari, sedangkan beton normal dengan substitusi serbuk kaca 50\% dan penambahan epoxy $10 \%$ mengalami kenaikan kuat tekan dari pada beton normal dengan substitusi serbuk kaca 50\% 
dengan rasio penurunan sebesar 0,89 pada umur 14 hari dan rasio penurunan sebesar 0,98 pada umur 28 hari.

2. Kuat lentur beton dengan substitusi serbuk kaca 50\% lebih besar dibandingkan dengan beton normal dan beton dengan penambahan epoxy $10 \%$ dan substitusi serbuk kaca $50 \%$.

3. Modulus elastisitas beton dengan substitusi serbuk kaca $50 \%$ sebesar $25813,05 \mathrm{MPa}$ selama 14 hari dan 32441,09 MPa selama 28 hari. Modulus elastisistas beton dengan substitusi serbuk kaca 50\% lebih tinggi dari pada beton normal dan beton dengan penambahan serbuk kaca $50 \%$ dan epoxy $10 \%$.

4. Penggunaan serbuk kaca lebih besar dari $50 \%$ dapat menurunkan nilai kuat tekan beton.

5. Penambahan serbuk serbuk kaca lebih besar dari 50\% dapaty menjadikan workability beton tidak begitu baik

\section{Daftar Pustaka}

Alkhaly, Y.R., Panondang, C.N., \& Zulfahmi. (2015). Kuat Tekan Beton Polimer Berbahan Abu Vulkanik Gunung Sinabung dan Resin Epoxy. Teras Jurnal, 5(2), 125-132

Arif, J., Husni, H.R., \& Sebayang, S. (2015). Pengaruh Resin Epoxy Terhadap Mortar Polimer Ditinjau dari Kuat Tekan, Kuat Tarik Belah, Daya Serap Air dan Scanning Electron Microscope. Jurnal Rekayasa Sipil dan Desain, (3)3, 361-370

Gemert, V. (2004). Cement Concrete and Concrete-Polymer Composites: Two Merging Worlds, A Report from $11^{\text {th }}$ ICPIC Congress. Belgium: Katolik Universiti Leuven.

Metode Pengujian Kuat Tekan Beton. SNI 03-1974-1990. Badan Standardisasi Nasional (BSN), Jakarta.

Metode Pengujian Waktu Ikat Awal Semen Portland Dengan Menggunakan Alat Vicat Untuk Pekerjaan Sipil. SNI 03-6827-2002. Badan Standardisasi Nasional (BSN), Jakarta.

Persyaratan Beton Struktural Untuk Bangunan Gedung. SNI 2847-2013. Badan Standardisasi Nasional (BSN), Jakarta.

Purnomo, H., \& Hisyam, E.S., (2014). Pemanfaatan Serbuk Kaca Sebagai Substitusi Parsial Semen pada Campuran Beton Ditinjau dari Kekuatan Tekan dan Kekuatan Tarik Belah Beton. Jurnal Teknik Sipil, 2(1), 45-55

Putri, F.E.G., \& Tanzil, G. (2013). Pengaruh Sulfat Terhadap Kuat Tekan Beton dengan Variasi Bubuk Kaca Substitusi Sebagian Pasir dengan w/c 0,6 dan 0,65. Jurnal Teknik Sipil dan Lingkungan, 1(1), 68-73

Putri, N.P., Kusumawati, D.H., \& Rohamwati, L. (2014). Sifat Mekanik Beton Polimer Epoxy dengan Pengisi Partikel Nanokalsit-silika. Jurnal Sains dan Matematika, 2(2), 38-41

Standart Test Method For Flexual Strenght of Concrete (Using Simple Beam With Center-Point Loading). ASTM C 293-94. ASTM International, West Conshohocken, PA.

Standard Test Method for Time Setting of Hydraulic Cement by Vicat Needle. Annual Book of ASTM Standards. C- 191. 2004. ASTM International, West Conshohocken, PA.

Suhartini, A., Gunarti, A.S.S., \& Hasan, A. (2014). Pengaruh Penambahan Tumbukan Limbah Botol Kaca Sebagai Bahan Substitusi Agregat Halus Terhadap Kuat Tekan dan Kuat Lentur Beton. Jurnal Bentang. 2(1), 66-80 
